\title{
Students leadership development through Tangkap Lokam game
}

\author{
Nisa Ariantini, Novi Rosita Rahmawati * \\ Universitas Borneo Tarakan. Jl. Amal Lama No.1, Kota Tarakan, Kalimantan Utara, Indonesia \\ Institut Agama Islam Negeri Kediri. Jl. Sunan Ampel No.7, Kota Kediri, Jawa Timur 64127, Indonesia \\ * Corresponding Author. E-mail: E-mail: novi.rahmawati92@gmail.com
}

Received: 29 October 2019; Revised: 5 November 2019; Accepted: 20 December 2019

\begin{abstract}
Games, such as the traditional ones, might be benefitted as an alternative media for the delivery of Guidance and Counseling service. With regards to the statement, one of the peculiar games in Indonesia is Tangkap Lokam. Through the conduct of the study, the elements of leadership will be described through the conduct of the Tangkap Lokam games. Then, within the conduct of the study, the qualitative approach using the symbolic interactionism method had been implemented and the study itself took place in the $5^{\text {th }}$ State Junior High School Tarakan. The results of the study show that the construction within the Tangkap Lokam game has implications that might improve the leadership of the students.
\end{abstract}

Keywords: Tangkap Lokam game; leadership

How to Cite: Ariantini, N., \& Rahmawati, N. (2019). Students leadership development through Tangkap Lokam game. Psychology, Evaluation, and Technology in Educational Research, 2(1), 63-68. doi:http://dx.doi.org/10.33292/petier.v2i1.33

\section{INTRODUCTION}

Playing games is one of the activities that adolescents like most and playing games might provide positive impacts to both the adolescents and their development (Adachi \& Willoughby, 2012; Deater-Deckard, Chang, \& Evans, 2013; Khoo, 2012; Kuo, Orsmond, Coster, \& Cohn, 2013). However, several phenomena in which adolescents become addicted to playing games have still been found (Gumus \& Dincel, 2016; Hazar, 2019; Oskenbay et al., 2016). With regards to playing games, in Indonesia alone many traditional games have been benefitted for the sake of education. These game have been frequently benefitted as part of learning media (M. R. Kurniawan, 2018; W. P. Kurniawan \& Zawawi, 2017; Munawaroh, 2017).

The provision of the appropriate technique in playing a game might develop the potentials of a student in accordance to his or her needs (Anita, Sugiyo, \& Suwarjo, 2013). In the same time, through playing games, a student might develop his or her interpersonal communication skills (Anita et al., 2013), build his or her characters (Nur, 2013), improve their sense of responsibility (Putri \& Ramli, 2016); and improve their social skills (Handayani, 2017; Parji \& Andriani, 2016).

One of the traditional games that have developed in Indonesia, especially in the region of Northern Borneo, is Tangkap Lokam. In general, this game is known as Bebentengan or Bentengan in other regions of Indonesia (W. P. Kurniawan \& Zawawi, 2017). This game can be played by several people and the objective of the game is to defend own Lokam (fortress) and to take over the Lokam (fortress) of the opponents in order to win. As having been implied by the name, the fortress becomes the main objective within the game.

Based on the results of the preliminary observation in the $5^{\text {th }}$ State Junior High School Tarakan, there are several terms that have appeared within the game namely: (a) attacker; (b) guardian; (c) prison; and (d) fort. The Tangkap Lokam game might serve as a place where the adolescents might express themselves. The involvement of the children within the game will improve and develop the adolescents' affective skills. Through the Tangkap Lokam game, the adolescents might develop their skills as a leader within the decision-making process. 
A leader has privilege and, consequently, the leader is different from any other people. In other words, a leader might be considered having superior capacities that others do not have (Bennis, 2006). However, every person has the capacities to be a leader (Muladi \& Sujatno, 2011). Thus, specific to the context of Tangkap Lokam, the role of a leader in Tangkap Lokami game might be carried by each group member.

On the other hand, a counselor in any school has basically pursued assistance toward the selfdevelopment and the alleviation of the students' problems. According to (Gibson, Santoso, \& Mitchell, 2010), guidance and counselling refers to the service of assistance that a counselor provides to the students both individually and communally so that the students might develop independently and optimally. In addition, (Nursalim, 2013) explains that guidance and counselling technique refers to all aspects that might be benefitted for channelling the guidance and counselling messages in order to review the mind, the feeling, the attention and the willingness of the counselee in understanding themselves, making decisions and solving the problems that have been encountered.

Furthermore, the guidance and counselling technique that a counselor adopts should be fun and interactive so that the delivery of the guidance and counselling service might be accepted by the students well (Putri \& Ramli, 2016). One of the techniques that a counselor might adopt in delivering the guidance and counselling service is Tangkap Lokam game. Through the implementation of the peculiar and unique method within the conduct of the guidance and counseling service both inside and outside the classrooms, the Guidance and Counselling Teachers will be assisted in developing the students' personality and social skills (Mappiare-AT, 2012). By providing the guidance and counseling service with Tangkap Lokam game as the basis, it is expected that a counselor in any school might assist the development of the students' leadership.

Therefore, the focus of the article is describing the elements of the students' leadership by using the Tangkap Lokam game. In addition, the discussions within the article is expected to serve as a matter of reference for the students, the school counselors and the future studies.

\section{METHOD}

Within the conduct of the study, the qualitative method had been adopted in order to uncover the phenomenon under hollistic-contextual manner through the data gathering activities within the natural setting by benefitting the researcher as the key instrument (Adam, Munadhir, \& Patasik, 2018; Ariantini, 2018). Then, the design that had been adopted within the conduct of the study was the symbolic-interactionism type. According to this type of design, a researcher contemplates on the interindividual interactions and the apparent symbols such as language, speaking rhythm, word emphasis, posture, gesture and mimic from the interaction that has been taking place and the meaning that individuals give to these symbols. Specific to the context of the study, the natural setting was the Tangkap Lokam game.

Furthermore, in gathering the sample the purposive sampling technique had been adopted. The subjects within the conduct of the study were 14 students from the $5^{\text {th }}$ State Junior High School Tarakan. These subjects were selected based on the following criteria: (1) the subject used to play Tangkap Lokam game; (2) the subject was cooperative to perform the game; (3) the subject might be the informant for the study; and (4) the subject established a warm relationship with the researcher. The study itself took place in the 5th State Junior High School located in Gunung Lingkas Street, District of East Tarakan, City of Tarakan, Province of North Borneo.

The presence and the involvement of the researcher in the field was intended to find the meaning and the interpretation of the subjects that might not be replaced by other tools (non-human aspects); in this occasion, the researcher used himself as the main instrument. Through the observation, the researcher served as the main observer in relation to the symbols that appeared from the interaction process within the activities of the Tangkap Lokam game. In the same time, the researcher served as the active instrument in performing the interview with regards to the symbols that had been resulted from the Tangkap Lokam game. Then, there were several techniques that had been adopted within the data analysis technique namely data description, data categorization and data connection. 


\section{RESULTS AND DISCUSSIONS}

In this section, the results that have been attained from the conduct of the study will be presented and will be discussed further. Both of the results and the discussions might be consulted in the following sub-sections.

\section{Results}

From the results of the review that has been performed, there are several data that have been found with regards to the conduct of the Tangkap Lokam game namely: (1) the leader trusts the group members to choose their own duty, allows the group members to share their opinion, is able to retrieve the feedback from the group members and holds meaningful discussions with regards to the game strategy; (2) the leader shares the idea that might contribute to one of the strategies within the game and renews the strength of the team or, in other words, the players execute the game in accordance to the regulations that have been agreed; and (3) the leader shows assertiveness in his attitudes toward the group members, arranges all of the group members' affairs and does not allow other group members to share their opinion.

\section{Discussions}

Basically, leadership might be categorized into three main groups namely: (1) leadership as an attribute or a position; (2) leadership as a characteristic; and (3) leadership as a behavioural category (Watkins, 1986). Leadership as an attribute refers to the type of special power relation that has been determined by an assumption that all of the group members have the power to define their behavioural patterns in relation to their activities as the group members (Janda, 1960). Then, leadership as a characteristic is defined as the fact that leader is an agent of change and a person who performs the action of influencing other people more than other person that strives to exert his or her influence onto the person (Ivancevich \& Gibson, 2005). Last but not the least, leadership as a behavioural category refers to the leadership that involves the process of inter-individual influence (Sweeney \& McFarlin, 2002); this process aims at motivating other people, creating future vision and developing strategies for achieving certain objectives.

Specific to the context of the study, the role of a leader in the Tangkap Lokam game is more of leadership as a behavioural category because the chief of the group leaders his members under the objective of executing the games in accordance to the strategies that might win the game. Then, departing from the results of the study, several implications might be discussed in relation to leadership as a behavioural category. First, the leader trusts his group members to define their own duty, allows the group members to share their opinion and is able to retrieve feedback from the group members. In relation to the argument by (Chiang \& Wang, 2012), in the group context trust consists of two dimensions namely cognitive trust and affective trust. Within the conduct of the Tangkap Lokam game, both dimensions are able to develop within the students and the statement is apparent in the action where the leader trusts the group members to define their own role within the game. Second, the leader displays contributes his ideas into one of the strategies within the game and renews the strength of the team. The implication of the statement is that the players perform the game in accordance to the regulations that have been agreed. In this case, the leader needs a good teamwork within his group. The second finding is in accordance to the argument by (Tarricone \& Luca, 2002): teamwork is defined as a process that holds common objective in which each member might develop the effectiveness and the reciprocal relationship in order to achieve the objective of the group. Within the Tangkap Lokam game, in order that each group member contributes the ideas into the fluent teamwork performance there should be good teamwork between the leader and the group members within the group. Third, the leader displays assertiveness in his attitude toward the group members, arranges all the group affairs and does not allow the group members to share their opinion. (Wooten, Hunt, LeDuc, \& Poskus, 2012) explains that the capacity of leading a group will develop through the activities of a game. The more developed the leadership of an individual is, the more the individual shows one of the leadership types that will be the peculiar characteristic of the individual.

With regards to the leadership type, there are two types of leadership that appears from the chief of the group namely the democratic leadership type and the authoritative leadership type. A chief of group with the democratic leadership type will assert his or her attitude by trusting the group members 
to define their own duty relative to their own capacity. In the context of the Tangkap Lokam game, each player is provided with an opportunity to share their opinion with regards to the strategy that the group should implement. In addition, the chief of the group is able to be a good listener by accepting all of the feedback that the group members have shared. Furthermore, the chief of the group also makes time to discuss the matters that he considers important for the group. In order to build democratic atmosphere, the initiatives that should be pursued are namely: (1) identifying numerous perspective among the group members; (2) identifying the genuine opinion from the group members; (3) recalling the social limitations; appreciating the personal opinions of the group members; and (4) asking for the loyalty of the group members (Soares \& Wood, 2010).

Then, the characteristics of democratic leadership type are as follows: (1) involving the group members in providing suggestions; (2) inviting the group members to collaboratively solve the problems that have been related to the given activities; (3) providing opportunity for the group members to share their opinion freely; (4) discussing openly the opinions that the group members have shared; and (5) sharing their thoughts for better and more innovative ideas in performing certain activities and solving problems (Ray \& Ray, 2012). The democratic leadership refers to the sacred values, awareness, assessment, motivation and courage (Molina \& Klinker, 2012). A democratic leader has loose control but is very active in stimulating group discussions and group decision-making activities. For a democratic leader, the policy or the decision is made communally, the communication is performed under two-way direction and the decision itself might come from the leader of the member.

On the other hand, the elements of the authoritative leadership that has developed within the Tangkap Lokam game are as follows: (1) arranging all of the group affairs: both the duty of the group members and the strategy that should be implemented; (2) maintaining strict attitude in the decisionmaking activities; (3) not giving opportunity for the group members to share their opinion; and (4) imposing the decision according to his will. The authoritative leadership refers to the high level of control without any freedom; according to this type of leadership, the group members are not allowed to take participation in the decision-making activities. An authoritative leader will not be willing to discuss about opinions and will dislike the participation of the group members in the decision-making activities. The authoritative leaders make their own decisions without having any consultation with the group members; the leader makes decision, communicates the decision to the group members and expects immediate implementation of their instruction (Boone \& Kurtz, 2009). In the situation of authoritative leadership that results in good impact, the leader encourages his or her members to cooperate so that the positive results might be delivered to the group (Al-Safran, Brown, \& Wiseman, 2014).

The Implication of the Tangkap Lokam Game for the Guidance and Counselling Service

The Tangkap Lokam game might be benefitted by the Guidance and Counselling teachers as one of the techniques for delivering the Guidance and Counselling service in the school. Unfortunately, this fact has not been understood yet by the Guidance and Counselling teachers in the school. (Mappiare-AT, 2012) states that through the provision of peculiar and unique service technique within the implementation of Guidance and Counselling service both inside and outside the classroom the Guidance and Counselling teachers will be assisted in developing the students' personality and social skills.

With regards to the Tangkap Lokam game, two types of leadership have appeared to the surface namely the democratic leadership and the authoritative leadership. The democratic leadership refers to the sacred values, the awareness, the assessment, the motivation and the courage (Molina \& Klinker, 2012). On the other hand, the authoritative leadership is unwilling to discuss opinions and dislikes the participation of the members in the decision-making process. The authoritative leaders make their own decisions without any consultation with the members; the authoritative leaders make their decisions, communicate their decisions to the members and expects immediate implementation of their instructions (Boone \& Kurtz, 2009). Based on the two types of leadership, the type of leadership that might have developed include the personal and the social domain of the students.

Gibson et al. (2010) explains that the implementation of Guidance and Counselling service might assist an individual in understanding himself or herself, in preventing the occurence of the problems, in being able to improve himself or herself and in pursuing optimum development through 
the information and the experience through group activities. In this regard, the Tangkap Lokam game might be benefitted as one of the Guidance and Counselling delivery technique for developing the leadership of the students, which implications might be related to the students' personal and social development.

\section{CONCLUSIONS}

Through the Tangkap Lokam game, the students are able to develop the different types of leadership within themselves. The role of the leader in the Tangkap Lokam game will develop the leadership of the students because the chief of the group leads the group members under the objective of winning the game in accordance to the strategy that will win the game. Every type of leadership, either the democratic one, the authoritative one or any other one, might exert certain influence to the group members. The given type of leadership will provide learning for the group members with regards to the manner that they will exert in serving as the leader in a group. Thus, it might be concluded that the Tangkap Lokam game might be benefitted as a technique in delivering the Guidance and Counselling service in order to help the students to develop their leadership.

\section{REFERENCES}

Adachi, P. J. C., \& Willoughby, T. (2012). Do video games promote positive youth development? Journal of Adolescent Research, 28(2), 155-165. https://doi.org/10.1177/0743558412464522

Adam, A., Munadhir, M., \& Patasik, J. R. (2018). Perilaku merokok pada kaum perempuan. Jurnal Berkala Kesehatan, 4(1), 30. https://doi.org/10.20527/jbk.v4i1.5667

Al-Safran, E., Brown, D., \& Wiseman, A. (2014). The effect of principal's leadership style on school environment and outcome. Research in Higher Education Journal, 22, 1-19. Retrieved from https://www.aabri.com/manuscripts/131666.pdf

Anita, D. A., Sugiyo, S., \& Suwarjo, S. (2013). Model layanan BK Kelompok teknik permainan (games) untuk meningkatkan keterampilan komunikasi interpersonal siswa. Jurnal Bimbingan Konseling, 2(1), 50-56. https://doi.org/10.15294/jubk.v2i1.1236

Ariantini, N. (2018). Kontruksi permainan Tangkap Lokam sebagai teknik konseling untuk peningkatan kecakapan sosial siswa. Universitas Negeri Malang.

Bennis, W. (2006). Moral leadership: The theory and practice of power, judgment and policy (Vol. 139). John Wiley \& Sons.

Boone, L. E., \& Kurtz, D. L. (2009). Contemporary business. John Wiley \& Sons.

Chiang, C.-F., \& Wang, Y.-Y. (2012). The effects of transactional and transformational leadership on organizational commitment in hotels: The mediating effect of trust. Journal of Hotel and Business Management, 1(1), 1-11.

Deater-Deckard, K., Chang, M., \& Evans, M. E. (2013). Engagement states and learning from educational games. New Directions for Child and Adolescent Development, 2013(139), 21-30. https://doi.org/10.1002/cad.20028

Gibson, R. L., Santoso, Y., \& Mitchell, M. H. (2010). Bimbingan dan konseling. Pustaka Pelajar.

Gumus, Y. Y., \& Dincel, S. (2016). Game addiction and academic achievement AU - Sahin, Mehmet. Educational Psychology, 36(9), 1533-1543. https://doi.org/10.1080/01443410.2014.972342

Handayani, P. (2017). Upaya peningkatan keterampilan sosial siswa melalui permainan tradisional congklak pada mata pelajaran IPS. Premiere Educandum: Jurnal Pendidikan Dasar Dan Pembelajaran, 7(1), 39-46. https://doi.org/10.25273/pe.v7i01.1245

Hazar, Z. (2019). Children's digital game addiction and opinions about their parents' playing digital games (A mixed method study). Journal of Education and Training Studies, 7(1), 85-93. https://doi.org/10.11114/jets.v7i1.3785

Ivancevich, J. M., \& Gibson, J. L. (2005). Organizations: behavior, structure, processes. Irwin Professional Pub.

Janda, K. F. (1960). Towards the explication of the concept of leadership in terms of the concept of power. Human Relations, 13(4), 345-363. https://doi.org/10.1177/001872676001300404 
Khoo, A. (2012). Video games as moral educators? Asia Pacific Journal of Education, 32(4), 416-429. https://doi.org/10.1080/02188791.2012.738638

Kuo, M. H., Orsmond, G. I., Coster, W. J., \& Cohn, E. S. (2013). Media use among adolescents with autism spectrum disorder. Autism, 18(8), 914-923. https://doi.org/10.1177/1362361313497832

Kurniawan, M. R. (2018). Permainan tradisional Yogyakarta sebagai sumber belajar alternatif berbasis kearifan lokal bagi pembelajaran di sekolah dasar. Premiere Educandum: Jurnal Pendidikan Dasar Dan Pembelajaran, 8(2), 98-111. https://doi.org/10.25273/pe.v8i2.2697

Kurniawan, W. P., \& Zawawi, M. A. (2017). Pengenalan permainan tradisional GOTENG (Gobak Sodor dan Bentengan) untuk membangun karakter siswa sekolah dasar kelas atas. Jurnal SPORTIF: Jurnal Penelitian Pembelajaran, 3(2), 128-141. https://doi.org/10.29407/js_unpgri.v3i2.11889

Mappiare-AT, A. (2012). Bimbingan dan konseling pada pendidikan dasar dalam perspektif perkembangan sosial budaya kontemporer. Bimbingan Dan Konseling Pada Pendidikan Dasar, 21(2), 178-187.

Molina, R., \& Klinker, J. F. (2012). A code of ethics for democratic leadership. International Journal of Leadership in Education, 15(3), 381-386. https://doi.org/10.1080/13603124.2011.617469

Muladi, \& Sujatno, A. (2011). Traktat etis kepemimpinan nasional \& indeks kepemimpinan nasional Indonesia. RMBooks.

Munawaroh, H. (2017). Pengembangan model pembelajaran dengan permainan tradisional engklek sebagai sarana stimulasi perkembangan anak usia dini. Jurnal Obsesi: Jurnal Pendidikan Anak Usia Dini, 1(2), 86-96. https://doi.org/10.31004/obsesi.v1i2.19

Nur, H. (2013). Membangun karakter anak melalui permainan anak tradisional. Jurnal Pendidikan Karakter, 3(1), 87-94. https://doi.org/10.21831/jpk.v0i1.1290

Nursalim, M. (2013). Pengembangan media bimbingan dan konseling. Jakarta: Akamedia.

Oskenbay, F., Tolegenova, A., Kalymbetova, E., Chung, M. C., Faizullina, A., \& Jakupov, M. (2016). Psychological trauma as a reason for computer game addiction among adolescents. International Journal of Environmental and Science Education, 11(9), 2343-2353. https://doi.org/10.12973/ijese.2016.800a

Parji, P., \& Andriani, R. E. (2016). Upaya peningkatan keterampilan sosial siswa melalui permainan tradisional congklak. Gulawentah: Jurnal Studi Sosial, $1(1), \quad 14$. https://doi.org/10.25273/gulawentah.v1i1.27

Putri, S. A. P., \& Ramli, M. (2016). Pengembangan media permainan simulasi ular tangga untuk meningkatkan tanggung jawab belajar siswa SMP. Jurnal Kajian Bimbingan Dan Konseling, l(1), 40-46. https://doi.org/10.17977/um001v1i12016p040

Ray, S., \& Ray, I. A. (2012). Understanding democratic leadership: some key issues and perception with reference to india's freedom movement. Afro Asian Journal of Social Sciences, 3(3.1), 1-26.

Soares, L. B., \& Wood, K. (2010). A critical literacy perspective for teaching and learning social studies. The Reading Teacher, 63(6), 486-494. https://doi.org/10.1598/RT.63.6.5

Sweeney, P. B., \& McFarlin, D. B. (2002). Organizational behavior: Solutions for management. McGraw-Hill Irwin.

Tarricone, P., \& Luca, J. (2002). Successful teamwork: A case study. Higher Education Research and Development Society of Australasia.

Watkins, P. (1986). A critical review of leadership concepts and research: The implications for educational administration. Deakin University Press.

Wooten, B. M., Hunt, J. S., LeDuc, B. F., \& Poskus, P. (2012). Peer leadership in the cocurriculum: Turning campus activities into an educationally purposeful enterprise. New Directions for Higher Education, 2012(157), 45-58. https://doi.org/10.1002/he.20005 